\title{
Professor Clement Alfred Finch: hematologist, humanist, and mentor for many (July 4, 1915 - June 28, 2010)
}

\author{
Henry Wilde, Chitr Sitthi-amorn \\ Faculty of Medicine, Bangkok 10330, Thailand
}

\begin{abstract}
Clement Alfred Finch was a physician, researcher and educator who helped advance the scientific basis and practices of diagnosis and treatment of anemia since the time when little was known about the disease. He was born in New York, USA and graduated from medical school in 1941. He had a 60-year tenure at the University of Washington and published extensively (more than 300 scholarly articles and close to 30 key reviews). He was instrumental in collaborating with key Thai hematologists, particularly at the premier Siriraj Medical School. His contribution on iron metabolization in the bloodstream has been a corner stone of hematology. It included seminal research which led to the widespread supplementation with iron in diets by women to avoid iron deficiency anemia.
\end{abstract}

Clement Alfred Finch was born in upstate New York as the scion of two generations of physicians. He was educated at the University of Rochester Peter Bent Brigham Hospital, USA, and started publishing research results as a resident and fellow. He focused on the basic sciences and clinical aspects of hematology and soon became a "Guru" among North American workers in these fields. After a few years as a faculty member of Harvard Medical College, he was asked by Robert Williams to organize the Hematology Department of the then still new University of Washington Medical School in Seattle, USA. This, he accomplished with great success, making the University of Washington one of the main centers for research and training in physiology, pathophysiology and diseases of blood forming organs. "Metabolism of the Red Cell" is tightly bound to his name.

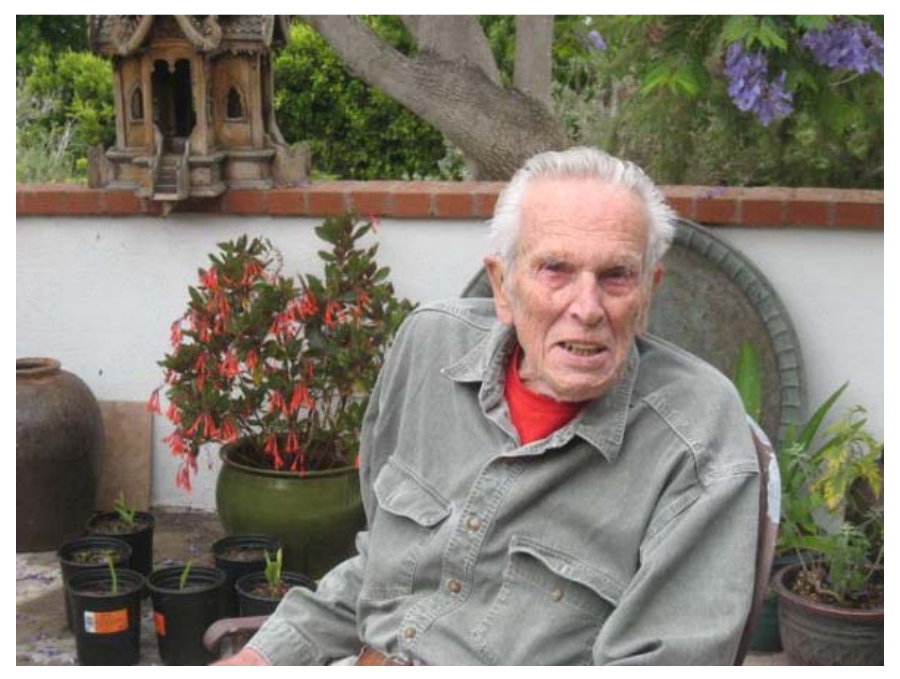

Fig. 1 Professor Clement Alfred Finch (1915-2010) at his home in the State of Washington, USA. 
There is no need to list all the academic honors and over 300 major publications of Clem Finch. There are many, and they can be readily retrieved from Pub Med. Examples of key studies include pathophysiologic aspects of sickle cell anemia [1], treatment of iron deficiency anemia in the adult [2], erythropoiesis in pernicious anemia [3], the diagnosis of iron deficiency anemia [4], and body iron excretion in man [5].

Clem opened his doors to Asian scholars, actually married one of them, and became a frequent visitor to Bangkok, Thailand. Many of Thai hematologists had the honor of co-authorship with Clem [6-8]. However, he was much more than a physician, scientist, and teacher. Clem was a giant of a man. One who observed our world with all its enormous social, political, and military problems and adventures of the mid to late $20^{\text {th }}$ Century. He had humor and the ability to make his students think beyond their work in science and medicine. He was an outdoorsman and liked to climb mountains in his beautiful State of Washington and in neighboring Alaska and even Peru. His skills allowed him to scale the wall of his lab building at the University of Washington once, when he forgot his keys on a Sunday. It quickly brought the police (or fire department) to retrieve him off the wall and made the Seattle Times newspaper. Clem is survived by his wife Genia, children: Clifton, Lisa,
Carin, and Derel, as well as many former students, particularly the hematologists from Thailand. Many are now found in senior clinical academic positions worldwide. They all will remember him for the rest of their lives. Several Thai professors and the author of this obituary are among them.

\section{References}

1. Finch AC. Pathophysiologic aspects of sickle cell anemia. Am J Med. 1972; 53:1-6.

2. Pirzio-Biroli G, Finch AC. Treatment of iron deficiency anemia in the adult. J Chronic Diseases. 1957; 6: 302-6.

3. Coleman DH, Finch CA. Erythropoiesis in pernicious anemia. Am J Med. 1953; 15: 412.

4. Bainton DF, Finch CA. The diagnosis of iron deficiency anemia. Am J Med. 1964; 37: 62-70.

5. Green R, Charlton R, Seftel H, Bothwell T, Mayet F, Adams B, et al. Body iron excretion in man: a collaborative study. Am J Med. 1968; 45: 336-53.

6. Pootrakul P, Josephson B, Huebers HA, Finch CA. Quantitation of ferritin iron in plasma, an explanation for non- transferrin iron. Blood. 1988; 71:120 -3.

7. Pootrakul P, Kitcharoen K, Yansukon P, Wasi P, Fucharoen S, Charoenlarp P, et al. The effect of erythroid hyperplasia on iron balance. Blood. 1988; 71:1124 -9.

8. Cazzola M, Pootrakul P, Huebers HA, Eng M, Eschbach J, Finch CA. Erythroid marrow function in anemic patients. Blood. 1987; 69:296-301. 